\title{
Maternal leucocyte zinc deficiency at start of third trimester as a predictor of fetal growth retardation
}

\author{
J L WELLS, D K JAMES, R LUXTON, C A PENNOCK
}

\begin{abstract}
Leucocyte zinc concentrations were measured in 70 mothers at the beginning of the third trimester of pregnancy and compared with the weight centiles of their subsequently delivered babies. The median maternal leucocyte zinc concentrations rose progressively with weight centile. Thus the median leucocyte zinc concentration of the mothers delivering babies weighing below the 10th centile was $112 \mathrm{nmol} / 10^{\circ}$ leucocytes and that of the mothers with babies weighing above the 90th centile was 229.5 nmol/10' leucocytes. A maternal leucocyte zinc concentration $<120 \mathrm{nmol} / \mathbf{1 0}^{\circ}$ leucocytes strongly predicted a baby weighing below the 10th centile (positive predictive value $=71.9 \%$, negative predictive value $=91 \cdot 5 \%$, sensitivity $=64 \cdot 3 \%$, specificity $=81 \cdot 8 \%$ ).

These findings suggest that maternal zinc concentration might have a role in antenatal screening, but larger studies are required.
\end{abstract}

\section{Introduction}

The weight of a tenth of all babies born in Britain lies below the 10th centile of the normal distribution of weight for age. Historically, the recognition that many of these low birthweight infants had suffered from growth retardation in utero was important ${ }^{12}$ as they form a group with special perinatal problems that has a high morbidity and mortality. ${ }^{34}$ All infants weighing below the 10th centile are generally agreed to be the victims of intrauterine growth retardation. ${ }^{5}$

Intrauterine growth retardation has many causes, but it is associated with certain fetal factors, such as genetic abnormalities ${ }^{6.8}$ and intrauterine infections, ${ }^{10}$ and with maternal factors, such as chronic illness, poor diet, ${ }^{11-14}$ pre-eclampsia, ${ }^{15}$ smoking, ${ }^{16}{ }^{17}$ and excessive alcohol intake during pregnancy..$^{18-20}$ In $30 \%$ of cases, however, no predisposing factors are found, and these are therefore said to be "idiopathic."

Zinc is an essential trace element for plant and animal life ${ }^{21}$ as it is required universally for the synthesis of nucleic acid and protein. It is necessary for growth, and its deficiency is associated with syndromes that cause short stature and dwarfism. ${ }^{22}{ }^{23}$ Recent interest has focused on the role of zinc in pregnancy and its effect on fetal growth and development. Various materials have been used to measure zinc state, including hair, urine, and blood (whole, plasma, and cellular components). For practical purposes we did not include hair and urine as source materials and concentrated on blood. Meadows $e t$ al showed that, though plasma zinc concentrations were unhelpful, leucocytes were a suitable nucleated tissue from which to assess zinc state. ${ }^{24} 25$ They found no association between either maternal or neonatal plasma zinc concentrations and baby size. Leucocyte zinc concentration declined in all mothers during the second trimester, remaining constant and low after 26 weeks. Both

University Department of Obstetrics, Southmead Hospital, Bristol BS10 5NB

J L WELLS, medical student

D K JAMES, MD, MRCOG, senior lecturer

University Department of Chemical Pathology and Child Health, Bristol Maternity Hospital, Bristol BS2 8EG

R LUXTON, MSC, FIMLS, senior medical laboratory scientific officer

C A PENNOCK, MD, FRCPATH, senior lecturer

Correspondence to: Dr James. the mothers of babies weighing below the 10th centile and their babies were found to have significantly lower leucocyte zinc concentrations at delivery than the mothers and babies in the cases where the babies had grown normally. This suggests that zinc depletion in both mother and fetus is associated with intrauterine growth retardation, but whether it is a cause of poor growth or merely a marker of pathological fetal growth is unclear.

We studied whether zinc state could be used as a reliable indicator of fetal growth retardation early in the third trimester of pregnancy.

\section{Patients and methods}

We studied 70 pregnant women booked for delivery at Southmead Hospital, Bristol. The women were recruited randomly from antenatal clinics between 28 and 34 weeks of pregnancy. Dates were confirmed in over $90 \%$ of the women in the first half of the pregnancy by ultrasonography. All gave informed consent before entering the study. We collected $10 \mathrm{ml}$ of heparinised venous blood from each mother during routine venesection in the antenatal clinic between 28 and 34 weeks, and information regarding maternal age, health, parity, smoking habits, and alcohol intake was recorded.

The infants were all delivered at Southmead Hospital. All were singleton live births; 37 of the babies were girls and 33 were boys. Thirteen $(20 \cdot 6 \%)$ were delivered by forceps, five by caesarean section $(7 \cdot 8 \%)$, and the remainder by normal vaginal delivery.

The birth weights of the infants were recorded at delivery by midwives (who had no knowledge of the leucocyte zinc assay results) using standard weighing scales. The birth weights ranged from $2200 \mathrm{~g}$ to $4400 \mathrm{~g}$ (mean 3360 g), and gestation ranged from 36 to 42 weeks (mean $39 \cdot 8$ weeks). The weight centiles of the infants were calculated from standard, sex adjusted weight charts. ${ }^{27}$ The mothers were divided into six groups according to the weight centiles of their baby: $\leqslant 10$ th (14 babies), 11-25th (11 babies), 26-50th (12 babies), 51-75th (15 babies), 76-90th (nine babies), and $>90$ th (nine babies). Any infant whose weight fell exactly between two centile groups was allocated to the higher centile group.

Twenty mothers smoked ( $28.6 \%$ overall), and eight of the 25 mothers with babies weighing below the 25 th centile smoked (32\%). Eleven mothers $(15 \cdot 7 \%)$ had various complications of pregnancy, including antepartum haemorrhage (four mothers), hypertension (four mothers), rhesus haemolytic disease (one mother), and gestational diabetes (two mothers).

Non-parametric statistical methods (Mann-Whitney U test and $\chi^{2}$ test with Yates's correction) were used to analyse the data.

The leucocytes were prepared by dextran sedimentation within 12 hours of venesection. ${ }^{26}$ Exactly $1 \mathrm{ml}$ white cell suspension was removed from the settled red cells and centrifuged to form a leucocyte pellet. After $1 \mathrm{ml}$ deionised distilled water had been added the white cells were resuspended using a Pasteur pipette. Then $1 \mathrm{ml} 1.8 \%$ saline was added within 15 seconds and mixed well. This procedure lysed any remaining red cells under osmotic conditions unlikely to lyse leucocytes. The washing procedure was repeated three times. The final leucocyte pellet was frozen and stored at $-20^{\circ} \mathrm{C}$ until all of the mothers had been recruited. The remainder of the leucocyte suspension was used for the measurement of the leucocyte concentration in the conventional way using a Coulter counter.

Before zinc content was measured the stored leucocyte pellet was first allowed to thaw by standing at room temperature then digested in $1 \mathrm{ml}$ concentrated nitric acid and made up to a total of $5 \mathrm{ml}$ with deionised water. This solution was centrifuged, and the zinc concentrations in the supernatant were measured on an Instrumentation Laboratories 353 atomic absorption spectrophotometer and compared with zinc standards treated in the same way as the leucocyte pellets. The final zinc concentration was expressed in terms of the leucocyte concentration of the initial leucocyte preparation.

Zinc contamination was minimised by using only acid washed glassware in the preparation of hydrolysates and "Aristar" grade reagents. In addition, a reagent blank was used to correct for any remaining small amounts of extraneous zinc. 


\section{Results}

\section{RELATION BETWEEN MATERNAL FACTORS AND BIRTH WEIGHT}

The mothers were all healthy, and none had any underlying medical condition known to be associated with fetal growth retardation. ${ }^{5}$ The women studied were predominantly from the lower social classes, but no correlation was found between social class and maternal leucocyte zinc concentration. None of the mothers showed evidence of excessive alcohol consumption.

Maternal age ranged from 15 to 37 years (mean 25.6 years). At recruitment 41 of the women $(58.6 \%)$ were nulliparous, and of the remainder, 20 had only one child. Two of the women were grand multiparas. At enrolment 20 mothers $(28.6 \%)$ admitted to smoking five or more cigarettes daily, but no together with the scatter of concentrations in each group, is also shown in the figure. There was a significant difference between the median zinc concentrations of the women in the $\leqslant 10$ th and those in the 11-25th centile group $(p<0.05)$ and a highly significant difference between the concentrations of the women in $\leqslant 10$ th and those in the $>90$ th group $(p<0.0005)$.

\section{PREDICTION OF INTRAUTERINE GROWTH RETARDATION FROM MATERNAL LEUCOCYTE ZINC CONCENTRATION}

From the figure a maternal leucocyte zinc concentration $<120 \mathrm{nmol} / 10^{9}$ leucocytes was selected to define low zinc concentration. Table II shows the

TABLE I-Relation between maternal factors and birthweight centile

\begin{tabular}{|c|c|c|c|c|c|c|c|}
\hline \multirow[b]{2}{*}{ Maternal factor } & \multicolumn{6}{|c|}{ Weight centile } & \multirow[b]{2}{*}{ Total } \\
\hline & $\leqslant 10$ th & 11-25th & 26-50th & 51-75th & $76-90$ th & $\geqslant 90$ th . & \\
\hline \multirow{2}{*}{$\begin{array}{l}\text { No }(\%) \text { of women } \\
\text { Mean age (years) } \\
\text { No }(\%) \text { of nulliparous women } \\
\text { No }(\%) \text { of smokers } \\
\text { No }(\%) \text { with pregnancy complications } \\
\text { Median leucocyte zinc concentration } \\
\text { (nmol/10 leucocytes) }\end{array}$} & $\begin{array}{c}14(20 \cdot 0) \\
23 \cdot 7 \\
8(57 \cdot 1) \\
4(28 \cdot 7) \\
2(14 \cdot 3)\end{array}$ & $\begin{array}{c}11(15 \cdot 7) \\
26 \cdot 0 \\
5(45 \cdot 5) \\
4(36 \cdot 4) \\
2(18 \cdot 2)\end{array}$ & $\begin{array}{c}12(17 \cdot 1) \\
22 \cdot 8 \\
8(66 \cdot 7) \\
3(25 \cdot 0) \\
1(8 \cdot 3)\end{array}$ & $\begin{array}{c}15(21 \cdot 4) \\
27 \cdot 1 \\
9(60 \cdot 0) \\
4(26 \cdot 6) \\
3(20 \cdot 0)\end{array}$ & $\begin{array}{c}9(12 \cdot 9) \\
28 \cdot 2 \\
5(55 \cdot 6) \\
2(22 \cdot 2) \\
2(22 \cdot 2)\end{array}$ & $\begin{array}{c}9(12 \cdot 9) \\
22 \cdot 6 \\
6(66 \cdot 7) \\
3(33 \cdot 3) \\
1(11 \cdot 1)\end{array}$ & $\begin{array}{l}70(100 \cdot 0) \\
25 \cdot 6 \\
41(58 \cdot 6) \\
20(28 \cdot 6) \\
11(15 \cdot 7)\end{array}$ \\
\hline & $11 \cdot 2$ & $15 \cdot 07$ & $16 \cdot 42$ & $19 \cdot 23$ & $21 \cdot 60$ & 22.95 & 16.56 \\
\hline
\end{tabular}

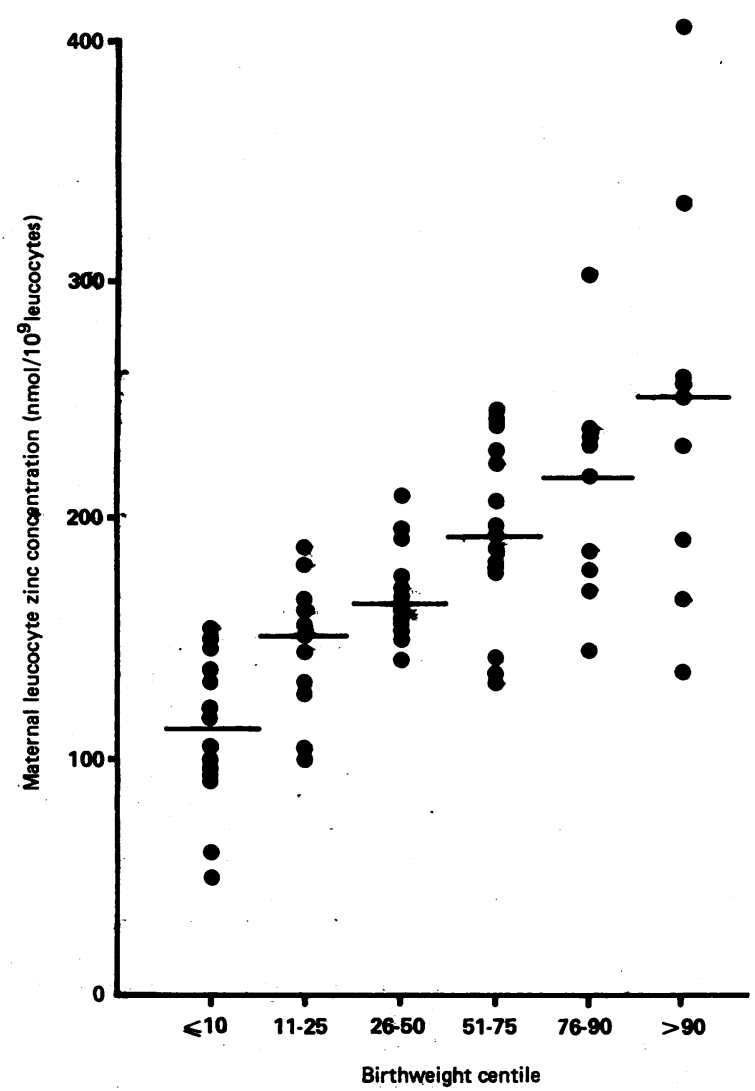

Maternal leucocyte zinc concentration and infant weight centile. Horizontal bars represent median values.

information was available regarding any changes in smoking habits that might have occurred during pregnancy. Complications of pregnancy (preeclampsia, antepartum haemorrhage, rhesus haemolytic disease, and preterm delivery) occurred in 11 of the mothers $(15 \cdot 7 \%)$. These maternal factors were found to be distributed uniformly among the different centile groups (table I).

Maternal leucocyte zinc concentration ranged from $48.8 \mathrm{nmol} / 10^{9}$ leucocytes to $405 \cdot 2 \mathrm{nmol} / 10^{9}$ leucocytes. Table I shows the median leucocyte zinc concentrations for the mothers in each centile group. This information, distribution of the 70 maternal leucocyte zinc concentrations in relation to this value and the subsequent birthweight centile. If this maternal leucocyte zinc concentration had been used to predict those infants who would weigh less than the 10th centile nine of the 14 cases of intrauterine growth retardation would have been detected (sensitivity $=64 \cdot 3 \%$ ). Two false positive results would also have been included (specificity $=81 \cdot 8 \%$ ). This maternal leucocyte zinc concentration therefore has a positive predictive value of $71.9 \%$ and a negative predictive value of $91.5 \%$ for fetal growth retardation.

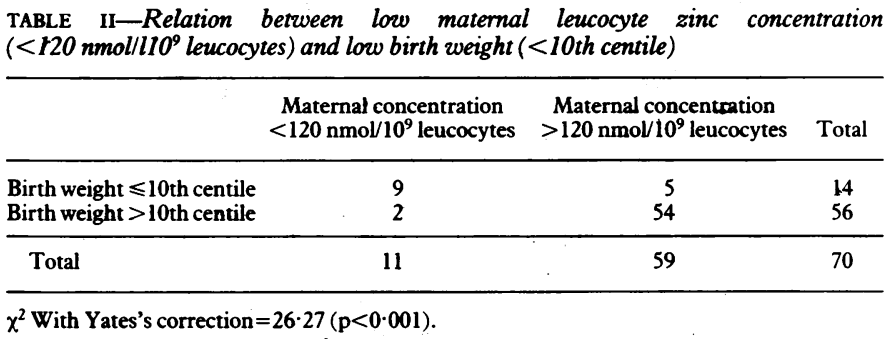

\section{Discussion}

The results show that early third trimester maternal leucocyte zinc concentrations are significantly associated with birthweight centile and may be used to predict intrauterine growth retardation at this stage of pregnancy. Our findings also support an association between maternal zinc deficiency and a small for dates fetus. $.^{24}, 33$ Summer and Thompson postulated that zinc state could be used to identify mothers at risk of delivering such babies, ${ }^{33}$ but they analysed maternal zinc state after birth, and thus our study is the first to show a predictive value of zinc concentrations during pregnancy. It is unlikely, however, that maternal leucocyte zinc concentration will ever be used widely as a screening test for fetal growth retardation as such testing is time consuming, requires great care, and has little advantage over the established clinical, hormonal, and ultrasound methods. ${ }^{28-30}$ Nevertheless, if the recently described zinc taste test is shown to be reliable in detecting zinc deficiency it might be used to identify mothers with zinc depletion, who are at risk of delivering a growth retarded infant. ${ }^{31}$ Alternatively, some form of dietary assessment might be used as a screening technique.

The range of values in our study was fairly large compared with 
the results of similar studies. ${ }^{24}$ 2s Our method of analysis of leucocyte zinc concentrations, however, was different: the zinc content was expressed as a function of leucocyte count, whereas other workers used leucocyte dry weight. ${ }^{24}{ }^{25}$ We have unpublished evidence to show that, provided the white cell preparation as described in this paper is undertaken within 12 hours of venesection, there is no significant white cell haemolysis. Any future study, however, should begin by comparing the two methods of measurement and their respective accuracies. In addition, white cells differ in their zinc content, and the precision of the method may be improved by considering the zinc content of only one class of white cells, such as the neutrophils.

Although this study contributed to the investigation of a possible role of maternal zinc deficiency in the aetiology of "idiopathic" fetal growth retardation, ${ }^{32}$ the number of women studied was too small to allow any useful conclusions to be drawn. The size of the study group also meant that the incidence of other risk factors for intrauterine growth retardation was low (of all the mothers, only 20 smoked and four had hypertension during pregnancy).

We thank Mrs Claire Saunders for secretarial help.

\section{References}

1 Warkany J, Monroe BB, Sutherland BS. Intrauterine growth retardation. Am $\mathcal{f}$ Dis Child 1961;102:249-79.

2 Gruenwald P. Chronic fetal distress and placental insufficiency. Biol Neonate 1963;5:215-65.

3 Allen MC. Development outcome and follow up of the small for gestational age infant. Semin Perinatol 1984;8:123-56.

4 Procianoy RS, Garcia-Prats JA, Adams JM, Silvers A, Rudolph AJ. Hyaline membrane disease and intraventricular haemorrhage in small for gestational age infants. Arch Dis Child 1980;55:502-5

5 Chiswick M. Intrauterine growth retardation. Br Med f 1985;291:845-8.

6 Ounsted M, Ounsted C. On fetal growth rate. In: Ounsted M, Ounsted C, eds. Clinics in Developmental Medicine. No 46. London: William Heinemann, 1973:18-26.

7 Polani PE. Chromosomal and other genetic influences on birthweight variation. In: Elliot $\mathrm{K}$, Knight J, eds. Size at birh. Amsterdam: Excerpta Medica, 1974:127-64. (Ciba Foundation Symposium No 27 .

8 Jones OW. Genetic factors in the determination of fetal size. 7 Reprod Med 1978;21:305-13.
9 Andreasson B, Svenningsen NW, Nordenfelt E. Screening for viral infections in infants with poor intrauterine growth. Acta Paediatr Scand 1981;70:673-6.

10 Primhoe RA, Simpson RM. Screening small for gestational age babies for congenital infection. Clin Pediatr (Phila) 1982;21:417-20.

11 Lechtig A, Klein RE. Pre-natal nutrition and birthweight: is there a causal association? In Dobbing J, ed. Maternal nutrition in pregnancy-eating for two. London: Academic Press, 981:131-56.

12 Briend A. Do maternal energy reserves limit fetal growth? Lancet 1985;i:38-40.

3 Metcalf J, Costiloe JP, Crosby W, et al. Maternal nutrition and fetal outcome. Am $\mathcal{F}$ Clin Nutr 1981;34:708-21.

14 Stein Z, Susser M. The Dutch famine 1944/45 and the reproductive process I: effects on 6 indices at birth. Pediatr Res 1975;9:70-6.

15 Rasmussen K, Thorup E, Giksen PS. Evaluation of the fetal circulation using Doppler ultrasound method in patients with pre-eclampsia and intra-uterine growth retardation. $\mathcal{f}$ Perinat Med 1984;12:257-9.

16 Lechtovirta $P$, Forss $M$. The acute effect of smoking on intervillous blood flow of the placenta. Br $\mathcal{F}$ Obstet Gynaecol 1978;85:729-31.

17 Cole PW, Hawkins LH, Roberts D. Smoking during pregnancy and its effect on the fetus. Fournal of Obstetrics and Gynaecology of the British Commonwealth 1972;79:782-7.

18 Ovellette EM, Rossett HL, Rosman NP, Weiner AB. The adverse effects of maternal alcohol abuse during pregnancy on offspring. N Engl I Med 1977;297:528-30.

19 Rossett HL, Weiner L, Lee A, Zuckerman B, Dooling E, Oppenheimer E. Patterns of alcoho consumption and fetal development. Obstet Gynecol 1983;61:539-46.

20 Little RE, Streissguth AP, Barr HM. Decreased birthweight in infants of alcoholic women who abstained during pregnancy. I Pediatr 1980;96:974-7.

21 Sien FE. Indispensability of zinc in nutrition of rats. Am $\mathcal{F}$ Physiol 1935;109:347.

22 Prasad RD. Zinc metabolism in patients with a syndrome of iron deficiency anemia hepatosplenomegaly, dwarfism and hypogonadism. F Lab Clin Med 1963;61:537.

23 Golden BE, Golven MHN. Plasma zinc and the clinic features of malnutrition. Am f Clin Nut 1979;32:2490-4.

24 Meadows NJ, Smith MF, Keeling WN, et al. Zinc and small babies. Lancet 1981;ii:1135-7.

25 Meadows NJ, Ruse W, Keeling PWN, Scopes JW, Thompson RPH. Peripheral blood leucocyte zinc depletion in babies with intrauterine growth retardation. Arch $D$ is Child 1983;58:807-9.

26 Baron J, Ahmed P. Intracellular concentration of water and of the principal electrolytes determined by the analysis of isolated human leucocytes Clin Sci 1969;37:205-19.

27 Gairdner D, Pearson JA. Growth chart for premature and other infants. Arch Dis Child 1971;46:783-7.

28 Belizon JM, Villar J, Nardin JC, Malamud J, de Vicina LS. Diagnosis of intrauterine growth retardation by a simple clinic method: measurement of uterine height. Am $\mathcal{f}$ Obstet Gynecol 1978;131:643-6.

29 Westergaard JG, Teisner B, Ham J, Grudzinskas JG, Chard T. Placental function studies in low birth weight infants with and without dysmaturity. Obstet Gynecol 1985;65:316-8.

30 Hadlock FP, Deter RL, Harnst RB. Sonographic detection of abnormal fetal growth patterns. Clin Obstet Gynecol 1984;27:342-51.

31 Bryce-Smith D, Simpson RI. Case of anorexia nervosa responding to zinc sulphate. Lancet 1984;ii:350.

32 Hytten FE. Commentary: do pregnant women need zinc supplements? $\mathrm{Br} \mathfrak{f}$ Obstet Gynaecol 1985;92:873-4.

33 Summer K, Thompson RPH. Maternal zinc and intrauterine growth retardation. Clin Sci 1984;68:395-9.

(Accepted 5 Februar. 1987)

\section{YEARS AGO}

The return of frosts and cold winds has brought home to all of us the need of warmer garments than have been worn during autumn, and medical men throughout the country are now busy impressing on their delicate patients the wisdom of adopting woollen underclothing, even in spite of cutaneous irritation. It may not be inopportune therefore at this season, and at a time when so many of our work-people are unemployed and half starving, to call attention to the fact that British hosiery is for all hygienic purposes, as well as for comfort, fully equal to those articles of woollen underclothing of foreign manufacture with which our markets are flooded, and which are vaunted as possessing special virtues. The all-wool hosiery and under-wear made in England, Ireland, and Scotland are in all respects as shapely and wholesome underclothes as any that are to be purchased, and can usually be had at a lower price than the imported goods which compete with them, and which, by dint of diligent puffing, have in some measure supplanted them. They are made of the finest and purest wool, unmixed with cotton or linen fibre, and of its natural colour, so that it is free from any injurious dye. They are of soft, elastic, open texture, being lightly milled or not at all in some cases, and thus afford a ready exit for all cutaneous exhalations, and contrast favourably with some German makes, especially in the thicker substances, which are heavily milled, brushed, and matted. They are made of various thicknesses, from a fine gauze up to a fleecy flannel, and can, therefore, be obtained suitable for summer, autumn, or winter wear, for those who are young, robust, and vigorous, and for those who are aged, infirm, or of very languid circulation. They are skilfuly shaped on anatomical principles, and really ensure a good fit, which their Continental rivals do not often do, as they are for the most part cut out of webbing. And, lastly, they are free from the clumsy and often irritating seams which are found in foreign underclothing, and are so well made that they stand wear and tear. Any medical man comparing Irish or Scotch, or the hygienic all-wool under-wear of the Donegal Industrial Fund, 43, Wigmore Street, London (made in Donegal), with German hosiery, will unhesitatingly give the preference to the former on all sanitary grounds. The popularity which the latter has obtained has really arisen out of exaggerated notions as to what it is possible for woollen clothing to accomplish in the preservation of health and the prolongation of life, together with an unreasonable faith in German science. In justice to our own work-people and manufactures, in these bad times it is desirable that a foolish prejudice which has been greatly to the detriment of a section of them, should be dissipated, and that British hosiery, under-wear, and homespuns should be rehabilitated in public esteem. And members of the medica profession can do more than any others to accomplish this, by assuring those who consult them that, in the hand-made hosiery made at their own doors, they have under-clothing of unsurpassed softness, cheapness, and durability, and in the all-wool home-spuns a clothing material, which is of the highest standard of durability and artistic merit, and which will ward off disease and promote health as faithfully and successfully as it is in the power of any underclothing to do. The all-wool hosiery and under-wear of the Donegal Industrial Fund received the Silver Medal of the Sanitary Institute of Great Britain and the Grand Diploma of Honour of the International Health Exhibition at South Kensington three years since. Since then great improvements have been made; and for hygienic value, purity of wool, shape, make, and price, it cannot be surpassed or indeed equalled by any foreign make. (British Medical fournal 1887;ii:1006.) 